\title{
EKSISTENSI SISTEM EKONOMI KAPITALIS di INDONESIA
}

\author{
Radlyah Hasan Jan
}

\begin{abstract}
Abstrak
Sistem ekonomi kapitalis di Indonesia dilatarbelakangi oleh perseteruan politik antara negara-negara barat yang dikenal dengan sebutan blok barat dan negaranegara timur atau yang dikenal sebutan blok timur. Blok barat dalam mengembangkan perekonomian menggunakan konsep sistem ekonomi kapitalis sedangkan blok timur mengembangkan sistem ekonomi sosialis. Namun, dengan berbagai kekuatan propaganda yang dimiliki oleh negara-negara barat tentang penerapan sistem ekonomi kapitalis maka pandangan masyarakat dunia jauh lebih baik jika dibandingkan dengan sistem ekonomi sosialis. Walaupun Indonesia sebagai anggota negara Non Blok (tidak memihak salah satu) Blok,namun pemerintah kita dalam menerapkan sistem ekonomi masih menggunakan sistem ekonomi kapitalis. Hal ini dapat dilihat beberapa indikator yang tetap digunakan pemerintah, yaitu: pertama,dihapuskannya berbagai subsidi dari pemerintah secara bertahap. Berarti, harga dari barang-barang strategis yang selama ini penentuannya ditetapkan oleh pemerintah, selanjutnya secara berangsur diserahkan sepenuhnya pada mekanisme pasar. kedua,nilai kurs rupiah diambangkan secara bebas (floating rate). Sesuai dengan kesepakatan dalam LoI dengan pihak IMF, penentuan nilai kurs rupiah tidak boleh dipatok dengan kurs tetap (fix rate). Dengan kata lain, besarnya nilai kurs rupiah harus dikembalikan pada mekanisme pasar. ketiga, privatisasi BUMN. Salah satu ciri ekonomi yang liberal adalah semakin kecilnya peran pemerintah dalam bidang ekonomi, termasuk didalamnya adalah kepemilikan asset-asset produksi. Dengan dijualnya BUMN kepada pihak swasta, baik swasta nasional maupun asing, berarti perekonomian Indonesia semakin liberal. keempat, peran serta pemerintah Indonesia dalam kancah WTO dan perjanjian GATT. Dengan masuknya Indonesia dalam tata perdagangan dunia tersebut, semakin memperjelas komitmen Indonesia untuk masuk kubangan libelarisasi ekonomi dunia atau kapitalisme global.
\end{abstract}

Kata Kunci: $\quad$ Sistem ekonomi kapitalis, Blok barat, Blok timur, Non Blok, Sistem ekonomi kapitalis, Sistem ekonomi sosialis, floating rate, IMF, privatisasi, WTO, GATT.

\section{Pendahuluan}

Sistem ekonomi kapitalis adalah sistem perekonomian yang memberikan kebebasan secara penuh kepada setiap orang untuk melaksanakan kegiatan perekonomian seperti memproduksi barang, menjual barang, menyalurkan barang dan lain sebagainya. Dalam sistem ini pemerintah bisa turut ambil bagian untuk memastikan kelancaran dan keberlangsungan kegiatan perekonomian yang berjalan, tetapi bisa juga pemerintah tidak ikut campur dalam ekonomi. Dalam perekonomian kapitalis setiap warga dapat mengatur nasibnya sendiri sesuai 
dengan kemampuannya. Semua orang bebas bersaing dalam bisnis untuk memperoleh laba sebesar-besarnya. Semua orang bebas malakukan kompetisi untuk memenangkan persaingan bebas dengan berbagai cara. Dalam berbagai paparan teoritis, kolonialisme, imperialisme, kapitalisme, dan globalisasi merupakan fenomena-fenomena yang terkait. ${ }^{1}$ Imperialisme berarti politik untuk menguasai (dengan paksaan) seluruh dunia untuk kepentingan diri sendiri yang dibentuk sebagai imperium. Menguasai disini tidak berarti merebut dengan kekuasaan senjata, tetapi dapat dijalankan dengan kekuatan ekonomi, kultur, agama, dan ideologi, asalkan dengan paksaan. Dalam definisi lain, imperialisme dikatakan sebagai upaya perluasan dengan paksaan wilayah satu negara dengan melakukan penaklukan teritorial yang menjadi dasar pembentukan dominasi politik dan ekonomi terhadap negara-negara lain yang bukan merupakan koloninya. ${ }^{2}$

Dalam semua definisi imperialisme, ada beberapa konsep yang selalu muncul: perluasan wilayah, penguasaan atau dominasi dengan paksaan (coercion), dan dominasi politik, budaya, serta ekonomi. V.I. Lenin menyatakan bahwa kapitalisme mencakup kapitalisme monopoli sebagai imperialisme untuk menemukan bisnis dan sumber daya baru. Ketika monopoli kapital finansial mendominasi, memaksa negara dan korporasi swasta bersaing untuk mengontrol sumber daya alam dan pasar. ${ }^{3}$ Kolonialisme sebagai salah satu aspek prahistori moda produksi kapitalis. Selain itu, teori imperialisme Marxist, dan teori dependensi yang terkait, menekankan pada hubungan ekonomi antar-negara (dan didalam negara-negara), alih-alih hubungan formal politik dan militer. Dengan begitu, imperialisme tidak selalu berupa satu hubungan kontrol yang formal satu negara atas negara lain, melainkan eksploitasi ekonomi satu negara atas negara lain. Dalam periodisasi yang lazim, imperialisme dibagi menjadi dua periode. Yang pertama adalah imperialisme kuno atau (ancient imperialism), yang intinya adalah prinsip gold, gospel, dan glory. Imperialisme ini berlangsung sebelum revolusi industri dan dipelopori oleh Spanyol dan Portugis. ${ }^{4}$

Periode kedua adalah imperialisme modern, yang intinya adalah kemajuan ekonomi. Imperialisme modern muncul sesudah revolusi industri. Industri besar-besaran membutuhkan banyak bahan mentah dan pasar yang luas. Para imperialis mencari jajahan untuk dijadikan

\footnotetext{
${ }^{1}$ Mubyarto, Reformasi Sistem Ekonomi: Dari kapitalisme menuju Ekonomi Kerakyatan, 1999, Aditya
} Media. h. 25

${ }^{2}$ Ibid.

${ }^{3}$ V.I. Lenin, The Highest Strage of Capitalism, 1916, h. 102

${ }^{4}$ Karl Marx, Capital : A Critique of Political Economi, 1909, h. 115 
sumber bahan mentah dan pasar bagi hasil-hasil industri kemudian juga sebagai tempat penanaman modal bagi surplus kapitalis. Unsur selanjutnya adalah kolonialisme. Kolonialisme merupakan pengembangan kekuasaan sebuah negara atas wilayah dan manusia diluar batas negaranya, seringkali untuk mencari dominasi ekonomi dari sumber daya, tenaga kerja, dan pasar wilayah tersebut. Definisi kolonialisme menyatakan bahwa kolonialisme merupakan satu praktik dominasi yang melibatkan subjugasi satu orang terhadap yang lain. Seperti imperialisme, kolonialisme juga melibatkan kontrol politik dan ekonomi terhadap satu teritorial yang dependen. Kolonialisme sangat sulit dibedakan dari imperialisme, satu-satunya perbedaan hanya dapat dilihat dari etimologi kedua konsep tersebut. Istilah koloni berasal dari kata Latin colonus, yang berarti 'petani'. Ini mengingatkan kita pada praktik kolonialisme yang biasanya melibatkan proses pemindahan populasi ke satu wilayah, di mana mereka akan tinggal di tempat tersebut secara permanen dan tetap mempertahankan afiliasi politik dengan negara asalnya. Disisi lain, imperialisme berasal dari kata Latin imperium, yang berarti 'memerintah'. Dengan demikian, imperialisme lebih merupakan cara bagaimana satu negara menjalankan kekuasaan atas negara lain, apakah melalui pembentukan koloni, kemakmuran, atau mekanisme kontrol tak langsung. Sementara itu, kapitalisme secara umum mengacu pada satu sistem ekonomi yang di dalamnya mencakup atau sebagian besar alat-alat produksi dimiliki secara privat dan dioperasikan demi keuntungan. Selain itu, dalam sistem ini, investasi, distribusi, pendapatan, produksi, dan penentuan harga barang-barang dan jasa ditentukan melalui operasi ekonomi pasar.

Kapitalisme biasanya melibatkan hak-hak individu dan sekelompok individu yang berperan sebagai "orang-orang legal" atau korporasi-korporasi yang memperdagangkan barangbarang kapital, buruh, dan uang. Ada beberapa pengertian lain soal kapitalisme. Yang pertama adalah kapitalisme merupakan sebuah sistem yang mulai terinstitusi di Eropa pada masa abad ke16 hingga abad ke-19, yaitu dimasa perkembangan perbankan komersial Eropa, dimana sekelompok individu maupun kelompok dapat bertindak sebagai suatu badan tertentu yang dapat memiliki maupun melakukan perdagangan benda milik pribadi, terutama barang modal seperti tanah dan tenaga manusia, pada sebuah pasar bebas dimana harga ditentukan oleh permintaan dan penawaran, demi menghasilkan keuntungan dimana statusnya dilindungi oleh negara melalui hak pemilikan serta tunduk kepada hukum negara atau kepada pihak yang sudah terikat kontrak yang telah disusun secara jelas kewajibannya baik eksplisit maupun implisit serta tidak semata- 
mata tergantung pada kewajiban dan perlindungan yang diberikan oleh kepenguasaan feodal. Yang kedua, kapitalisme adalah teori yang saling bersaing dan berkembang pada abad ke-19 dalam konteks Revolusi Industri, dan abad ke-20 dalam konteks Perang Dingin, yang berkeinginan untuk membenarkan kepemilikan modal, untuk menjelaskan pengoperasian pasar semacam itu, dan untuk membimbing penggunaan atau penghapusan peraturan pemerintah mengenai hak milik dan pasaran. Ketiga, kapitalisme dianggap sebagai suatu keyakinan mengenai keuntungan dari menjalankan hal-hal semacam itu. Keempat, kapitalisme adalah suatu sistem ekonomi yang mengatur proses produksi dan pendistribusian barang dan jasa dengan ciriciri: sebagian besar sarana produksi dan distribusi dimiliki oleh individu; barang dan jasa diperdagangkan di pasar bebas (free market) yang bersifat kompetitif; dan modal kapital (baik uang maupun kekayaan lain) diinvestasikan kedalam berbagai usaha untuk menghasilkan laba (profit). Kapitalisme sebagai " a mode of social organization characterized by the domination of exchange relation". Lebih jauh lagi, hubungan partikular antara yang abstrak dan yang konkret, atau antara gagasan-gagasan dan hal-hal, yang relevan bagi materialisme historis sebagai satu moda analisis kapitalisme, berakar pada hubungan nyata antara yang abstrak (relasi pertukaran) dan yang konkret (pengalaman hidup individu, tenaga kerja, dsb.). ${ }^{5}$ Ada beberapa elemen kunci yang kerap disebut dalam pendefinisian kapitalisme: sistem, modal (kapital), kepemilikan individu, proses produksi, kompetisi, pasar bebas, investasi, dan profit. Kata-kata kunci ini menjadi faktor determinan dalam implikasi-implikasi praktis operasi kapitalisme dan itu akan terlihat dalam sejarah panjang perkembangan kapitalisme. Pada umumnya para sejarawan ekonomi sepakat bahwa kapitalisme sebagai moda pengorganisasian kehidupan sosial dan ekonomi tidak hanya dimulai disatu tempat didunia, dalam hal ini Eropa Barat Laut, melainkan sejak tahap sangat awal, ketika masih dalam proses pembentukan pada abad ke-16, yang melibatkan ekspansi keluar yang secara bertahap melintasi wilayah-wilayah yang kian luas di dunia dalam satu jaringan pertukaran materi. Jaringan pertukaran materi ini seiring waktu berkembang menjadi pasar dunia bagi barang-barang dan jasa, atau bagi pembagian kerja internasional (division of labour). ${ }^{6}$

${ }^{5}$ Nicolas Garnham, Capitalism and Communication Global Culture and The Economics of Information, 1999. h. 22

${ }^{6}$ Ibid. 
Pada akhir abad ke-19, proyek satu ekonomi dunia yang kapitalistik telah terbangun dalam arti bahwa lingkup hubungan-hubungan mencakup semua wilayah geografis dunia. Abad ke-19 secara khusus mencuat sebagai waktu utama perkembangan pembagian kerja internasional. Diperkirakan bahwa dalam tiap dekade pada abad ke-19, perdagangan dunia tumbuh 11 kali lebih cepat dari produksi dunia, dan pada 1913, saat Perang Dunia I, 33 persen produksi dunia diperdagangkan diluar batas nasional negara-negara ${ }^{7}$. Revolusi Industri yang terjadi hampir di seluruh masyarakat Barat, terutama pada abad ke-19 dan awal abad ke-20bersama berbagai perkembangan yang terkulminasi menjadi transformasi dunia Barat dari masyarakat agriluktur menjadi satu sistem masyarakat Industri-memunculkan satu sistem masyarakat di mana muncul birokrasi ekonomi yang besar untuk melayani banyak kebutuhan industri dan sistem ekonomi kapitalis yang baru muncul. Sasaran ideal dari sistem kapitalisme ini adalah pasar bebas, dimana berbagai produk industri dapat ditransaksikan. ${ }^{8}$ Bagian dari dunia yang kini disebut sebagai Dunia Ketiga, yakni Amerika Selatan, Afrika, Asia-terkecuali Jepang, berpartisipasi secara penuh dalam pasar internasional. Pada 1913, Dunia Ketiga menangkap 50 persen pasar dunia (bandingkan dengan 22 persen saat ini). ${ }^{9}$

Praktik ekonomi kapitalistik terinstitusional di Eropa antara abad ke-16 dan ke-19 dan bentuk awal kapitalisme perdagangan (merchant capitalism) berkembang pada abad pertengahan. Menurunnya feodalisme pada saat itu mengikis kekangan politis dan religius tradisional dalam pertukaran-pertukaran kapitalis. Hal-hal yang menyulitkan terjadinya akumulasi kapital, seperti tradisi dan kontrol, aturan-aturan aristokrasi, yang mengambil alih kapital melalui denda secara sewenang-wenang, dan pajak, pada abad ke-18-berhasil diatasi dan kapitalisme menjadi sistem ekonomi yang dominan di United Kingdom dan pada abad ke-19 kapitalisme menjadi sistem ekonomi dominan di Eropa. Setelah menguasai Eropa, kapitalisme secara bertahap menyebar dari Eropa, khususnya dari Britania, melintasi batas-batas politik dan budaya. Pada abad ke-19 dan 20, kapitalisme menyediakan perangkat-perangkat utama industrialisasi ke sebagian besar penjuru dunia. Periode awal kapitalisme atau merchant capitalism atau merkantilisme ini juga disebut sebagai kapitalisme perdagangan. Periode ini dikaitkan dengan penemuan-penemuan oleh pedagang-pedagang lintas negara, terutama dari

\footnotetext{
${ }^{7}$ Hoogvelt. Globalization and the postcolonial World, Johns Hapkins University press, 1997. h.14

${ }^{8}$ George Ritzer, Modem Sociological Theory, 1996, h.6-7.

${ }^{9}$ Hoogvelt, Globalization and the postcolonial World, Johns Hapkins University press, 1997, h. 14
} 
Inggris dan Negara-Negara Dataran Rendah, kolonisasi Eropa terhadap Amerika, dan pertumbuhan pesat perdagangan lintasnegara. Merkantilisme adalah sistem perdagangan demi profit, meskipun sebagian besar komoditas masih diproduksi oleh metode produksi nonkapitalis. Di bawah merkantilisme, para pedagang Eropa, dengan dukungan kontrol, subsidi, dan monopoli negara, mendapatkan keuntungan dari pembelian dan penjualan barang-barang. Tujuan merkantilisme adalah "the opening and well-balancing of trade; the cherishing of manufacturers; the banishing of idleness; the repressing of waste and excess by sumptuary laws; the improvement and husbanding of the soil; the regulation of prices...". 10

Para perintis merkantilisme menekankan pentingnya kekuatan negara dan penaklukan luar negeri sebagai kebijakan utama dari kebijakan ekonomi. Jika sebuah negara tidak mempunyai bahan mentahnya, maka mereka mesti mendapatkan koloni yang akan menjadi sumber bahan mentah yang dibutuhkan. Koloni juga akan berperan sebagai pasar barang jadi. Agar tidak terjadi kompetisi, koloni harus dicegah untuk melaksanakan produksi dan dengan pihak lain. Dalam situasi ini, terwujudlah pembagian kerja (division of labor) internasional. Seperti dikatakan oleh Immanuel Wellerstein, kita menyebut pembagian kerja internasional ini sebagai ekonomi dunia kapitalis karena kriteria definitifnya adalah produksi barang dan jasa untuk dijual di pasar yang tujuannya adalah untuk memaksimalkan profit. ${ }^{11}$

Dalam pasar kapitalistik, kekuatan permintaan dan penawaran yang tampaknya netrallah yang menentukan harga satu produk dan dengan demikian memberi sinyal kepada produsen apakah mereka mesti melakukan ekspansi produk, mengurangi output, atau mengubah teknik produksi, mengurangi struktur biaya, dan sebagainya. Dengan kata lain, melalui medium tangan tak terlihat (invisible hands) ${ }^{12}$ yang telah menjadi "global invisible hand" pada akhir abad ke-19, aktivitas manusia dikoordinasikan secara rapi melintasi batas-batas nasional. ${ }^{13}$ Dari uraian-uraian diatas, terlihat bahwa ada beberapa hal yang selalu muncul dalam pembahasan kritis soal kolonialisme, imperialisme, dan kapitalisme. Beberapa karakter tersebut adalah penguasaan, baik secara (coercion atau non-coercion), eksploitasi (baik terhadap sumber daya alam dan manusia atau pada pemikiran), keuntungan atau profit (bagi negara-negara pelaku, yang selalu berasal dari

\footnotetext{
${ }^{10}$ Francis Bacon, The Seventeenth Century, 1961. h. 97

${ }^{11}$ Hoogvelt, loc. cit.

${ }^{12}$ Adam Smith, The Wealth of Nations, 1776. h. 226

${ }^{13}$ Hoogvelt, op. cit., h.15
} 
Eropa Barat dan Amerika Utara), ekonomi (yang menjadi latar belakang pendorong), dan hubungan yang sarat dengan ketidaksetaraan (satu atau sekelompok diuntungkan dan yang lain dirugikan). Ketiga konsep tersebut dalam analisis yang fokus pada pendekatan historis maupun analisis, kerap berkaitan satu sama lain. Itu bisa terlihat dari teori periodisasi dibawah ini. Sejumlah ilmuwan yang fokus pada sistem dunia memunculkan proposisi soal periodisasi perkembangan kapitalisme, yang didalamnya karakteristik kapital inti dan hubungannya dengan wilayah periferal sangat beragam.

Perbedaan-perbedaan itu dilihat sebagai satu hasil dialektis dari kontradiksi-kontradiksi yang ditimbulkan dalam tiap periode interaksi. Para ilmuwan Neo-Marxist, seperti Samir Amin, Andre Gunder Frank, Ernest Mandel, Albert Szymanski, dan Harry Magdoff, secara umum mengidentifikasi tahap prakompetitif merkantilis (1500-1800), tahap kapitalis kompetitif (18001880), tahap monopoli, imperialis (1880-1960), dan beberapa ilmuwan bahkan mengidentifikasi satu tahap monopoli imperialis/kapitalis lanjutan (yang dimulai oleh krisis pada 1968). Dalam tiap periode, periferi menjalankan fungsi tertentu dalam melayani kebutuhan-kebutuhan esensial akumulasi di sentral. Namun, kebutuhan-kebutuhan esensial ini berubah akibat hasil gemilang pelayanan tersebut. Dan karena interaksi dialektis antara core dan periferi memunculkan tingkat perbedaan perkembangan yang kian meningkat di core dan periferi dalam tiap periode, core dan periferi terpisah kian jauh, menuju satu titik krisis dalam hubungan tersebut, yang kemudian diatasi dengan mengubah struktur formalnya dan metode akstraksi surplus dari core ke periferi.

Sementara itu, munculnya periodisasi ekspansi kapitalisme yang berbeda. Periodisasi yang disebutnya sebagai periodisasi yang dikatakan merupakan periodisasi yang "mengabaikan variasi geografis yang luas”, ekspansi kapitalisme dapat dibagi menjadi empat periode. Yang pertama adalah fase merkantilisme, transfer surplus ekonomi melalui penjarahan dan perampasan yang disamarkan menjadi perdagangan (1500-1800). Kedua, periode kolonial, transfer surplus ekonomi melalui syarat-syarat pedagangan yang tak setara yang dilakukan melalui pembagian kerja internasional yang dilakukan melalui kolonialisme (1800-1950). Yang ketiga adalah periode neo-kolonial, transfer surplus ekonomi melalui developmentalism dan technological rents (1950-70). Yang terakhir adalah pascaimperialisme, transfer surplus ekonomi dilakukan melalui peonage (upaya membuat pengutang melakukan segala sesuatu bagi terutang) utang (1970-saat ini). Tahap pascaimperialisme, pada akhir abad ke-20, ditandai dengan pertumbuhan 
eksplosif perusahaan-perusahaan transnasional, yang memicu munculnya postimperialism theory. ${ }^{14}$ Sejarah ekonomi Barat, selama akhir abad ke-19 dan setelahnya, korporasi-korporasi menjelma menjadi organisasi ekonomi yang paling efisien dalam lingkup transportasi, komunikasi, produksi, distribusi, dan pertukaran yang semakin luas. ${ }^{15}$ Sementara itu, masih dalam kaitannya dengan periodisasi kapitalisme, periodisasi kapitalisme itu sebagai bagian dari analisis makro sistem komunikasi massa.

Pembabakan sejarah atau perkembangan historis trend "pengembangan imperium", yang pada dasarnya menggambarkan perkembangan dominasi, yang amat mirip dalam perkembangan sejarah kapitalisme, kolonialisme, dan imperialisme, terutama dari perspektif modernisasi. Trend pertama dalam pengembangan imperium adalah melalui penaklukan militer, disebut sebagai kolonialisme militer. Yang kedua adalah penaklukan oleh tentara salib Kristen, yang ia sebut sebagai kolonialisme Kristen. Yang berikutnya adalah kolonialisme merkantilisme, yang ia sebut bertahan hingga pertengahan abad ke-20. Satu elemen kunci yang sangat penting dalam kolonialisme merkantilisme, penemuan mesin cetak oleh Johannes Gutenberg karena hal itu memungkinkan terjadinya penyebaran pesan secara cepat dan lebih luas. Berakhirnya PD I dan PD II menandai berakhirnya era kolonialisme militeristik dan menempatkan negara-negara industri sebagai pemimpin jalur vital perdagangan dan praktik komersial global. Ini semua membawa dunia pada periode keempat perkembangan imperium, yakni kolonialisme elektronik. Periode ini diwarnai oleh ketergantungan less developed countries (LDC's) pada Barat, yang terjadi karena ada ketergantungan perangkat keras komunikasi yang vital dan perangkat lunak yang cuma diproduksi di barat. Selain itu, LDC's juga amat bergantung pada Barat dalam hal kebutuhan para insinyur, teknisi, yang protokol-protokol yang berkaitan dengan informasi, yang semuanya membentuk sekumpulan norma-norma, niai, nilai, dan ekspektasi asing, yang dalam berbagai tingkat berbeda mengubah budaya, kebiasaan, nilai-nilai dan proses sosialisasi domestik. Semua pemaran ini disebut sebagai electronic colonialism theory (ECT). Modernitas dan pascamodernitas merepresentasikan dua fase kapitalisme yang berbeda. ${ }^{16}$

Pasca modernitas berhubungan dengan late capitalism atau satu fase kapitalisme multinasional, "informational", dan "consumerist". Sementara itu, Harvey mendeskripsikannya

\footnotetext{
${ }^{14}$ Ibid, h. 16

${ }^{15}$ Becker, Sklar \& Hakim, Globalisasi, Kapitalim Global dan Media : Media Global, 1999. hal. 11

16 Thomas L. Mcphail , Global Communication : Theories Stakeholders and Trends, 2002. h. 187
} 
sebagai transisi dari Fordism ke akumulasi fleksibel. Gagasan yang sama juga muncul dalam teori-teori "disorganized capitalism". Pascamodernitas dengan demikian berhubungan dengan satu fase kapitalisme di mana produksi massa barang-barang standar dan bentuk-bentuk pekerjaan yang berkaitan dengan hal itu, telah digantikan oleh fleksibilitas: bentuk baru produksi. ${ }^{17}$ Periodisasi melibatkan lebih dari sekadar menelusuri proses perubahan. Memproposisikan satu pergeseran sama artinya dengan menentukan mana yang esensial dalam mendefinisikan satu bentuk sosial seperti kapitalisme. Pergeseran epokal berkaitan dengan transformasi-transformasi dasar dalam beberapa elemen konstitutif dasar satu sistem. ${ }^{18}$

Dengan kata lain, periodisasi kapitalisme bergantung pada bagaimana kita mendifinisikan sistem ini sejak awal. Dalam hal ini kita harus memahami bagaimana konsep-konsep modernitas dan pasca-modernitas menjelaskan bagaimana orang menggunakan konsep-konsep itu untuk memahami kapitalisme. Dalam kesimpulann bahwa modernitas telah mati, digantikan oleh kapitalisme. Apa pun fokus dan penggunaan istilahnya, baik imperialisme, kolonialisme, maupun kapitalisme, ada beberapa kesamaan dan warna serta jenis penaklukan dalam periodisasiperiodisasi yang digambarkan diatas. Secara umum, semua periodisasi dimulai dengan penaklukan militer yang dilanjutkan dengan perdagangan sekaligus ekspansi geografis. Pada akhirnya, periodisasi ditutup dengan hilangnya atau minimnya peran kekuatan koersif militer dalam penaklukan dan dominasi. Era terakhir dalam tiap periodisasi selalu di warnai oleh semakin dominannya unsur-unsur komunikasi dan media komunikasi dalam moda penaklukan, penguasaan, dan dominasi yang lebih halus, yang melibatkan nilai-nilai, norma-norma, dan halhal yang jauh dari kesan koersif. Periode terakhir, kolonialisme elektronik sebagai satu periode dimana para kolonialis "seeks mind", sedangkan kolonialisme masih "sought cheap labor". Secara implisit, ada pergeseran fokus dominasi: dari sesuatu yang bersifat kasar, jelas terlihat, dan fisik menjadi sesuatu yang halus, laten, dan psikis serta mental. Dominasi pada era ini amat sejalan dengan konsep hegemoni Antonio Gramsci.

${ }^{17}$ Jameson, The Cultural Logic of late Capitalism, 1991.

${ }^{18}$ McChesney, Wood \& Foster, Capitalism and The Information Age : the Political Economy Of The Global Comunication Revolution, 1998. 


\section{Implementasi Sistem Ekonomi Kapitalis Secara Global}

Pada saat ini, banyaknya modal (uang) yang terjadi dalam transaksi saham internasional, obligasi dan mata uang. Penerapan teknologi komunikasi elektronik telah menjadikan jumlah uang (modal) yang begitu besar dapat ditransfer ke seluruh dunia dalam sekejap. Pergeseran terkombinasi pada sebagian besar pasar modal dalam satu hari adalah equivalen (atau setara) dengan pergeseran dalam perdagangan internasional dalam satu tahun. Kesamaannya adalah kebenaran transaksi dalam pasar uang utama. Tetapi fakta yang berlainan ini mengindikasikan bahwa lebih dari 90\% dari transaksi-transaksi ini berbasis pada gerakan "mengambang" uang kertas, yakni, secara esensial bersifat spekualtif. Persamaan tersebut benar untuk jumlah modal uang yang besar yang diinvestasikan di pasar saham dunia. Semenjak "crash" pasar modal pada Oktober 1987, jumlah uang kertas yang diinvestasikan di saham-saham perusahaan telah meningkat lebih dari 25\% di Itali dan Kanada, lebih dari 50\% di AS, Jerman, dan Inggris serta lebih dari $100 \%$ di Perancis. Ini telah menghasilkan peningkatan yang tak terprediksikan dalam harga saham. Tentu, semakin tinggi harga suatu saham perusahaan semakin rendah nilai relatif dividennya (pembagian keuntungan) dari produksi yang didistribusikan kepada setiap pemegang saham.

Dalam realitasnya, hanya sedikit investor akhir-akhir ini yang membeli saham dengan tujuan mendapat bagian keuntungan sebuah perusahaan yang dihasilkan melalui produksi dan penjualan komiditinya. Poin dari jual beli di pasar modal adalah spekulasi, menjual dan membeli saham di perusahaan-perusahaan (sembarangan perusahaan) dengan harapan menghasilkan keuntungan yang cepat dengan memprediksikan bilamana orang-orang lainnya akan membeli dan menjualnya besok, atau dalam lima menit mendatang. Bagian yang terpenting dari uang kertas yang "mengambang" ini berisi apa yang disebut sebagai modal "fiktif" atau "imajiner" yang berlawanan dengan realitas, produktif, komoditi, dan modal. Obligasi pemerintah, contohnya, mewakili titel legal atas sebuah bagian dari pendapatan pemerintah di kemudian hari, misalnya, dari sektor perpajakan. Modal (uang) yang digunakan untuk belanja negara salah satunya diperoleh dari penjualan obligasi dan obligasi itu diperjual-belikan oleh negara, misalnya, ia telah menjadi pinjaman bagi pemegang obligasi tersebut. Tetapi karena pemegang 
obligasi menerima bunga dari pinjaman ini, dan dapat menjualnya sebagai komoditi, kemudian obligasi tersebut berlaku sebagai modal. ${ }^{19}$

Surat Pengakuan utang ini yang ditujukan untuk sebuah peminjaman (pemberian utang) tapi ketika diperjual-belikan, surat ini membiakkan modal yang tak tampak (annihiliated capital), yang berfungsi untuk dimiliki sebagai modal sejauh surat tersebut bisa diperjual-belikan selayaknya sebuah komoditas dan bisa dirubah menjadi modal. ${ }^{20}$ Saham dalam perusahaanperusahaan bermodal gabungan adalah titel kepemilikan modal yang riil. Mereka tidak bisa mengontrol modal yang ada karena modal tersebut tidak bisa ditarik kembali sejak modal atau saham itu terikat dalam bangunan, mesin, bahan mentah, dan sebagainya.Tetapi titel ini nampak menjadi kertas duplikat modal riil, seolah-olah sebuah bill of lading (sebuah perintah pengambilan kargo DL) yang secara simultan mencerminkann sebuah nilai dari kargo tersebut. Mereka menjadi nominal yang mewakili modal tak-eksis. Dalam persaingan yang bebas, perusahaan yang besar akan senantiasa "memakan" perusahaan yang kecil. Oleh karena itu, jumlah majikan akan semakin berkurang, sebaliknya jumlah kaum buruh akan semakin banyak. Demikian juga, jumlah perusahaan yang besar juga akan semakin sedikit, namun akumulasi kapitalnya akan semakin besar. Jika jumlah buruh semakin banyak, maka akan berlaku hukum upah besi (the iron wages law). Dengan demikian, nasib kaum buruh akan semakin tertindas sedangkan para kapitalis akan semakin ganas dan serakah.

Perkembangan kapitalisme global di abad mutakhir ini sudah semakin canggih dan kompleks. Keserakahan kaum kapitalis tidak hanya sampai pada pemerasan kaum buruh dan pencaplokan pengusaha kelas teri, namun keserakahan mereka sudah menerobos dan menjarah di banyak sektor yang lain, bahkan dengan dukungan berbagai fasilitas dan lembaga yang mereka ciptakan sendiri. Kaum kapitalis tidak hanya ingin membesar, tetapi mereka juga ingin membesar dengan cepat. Caranya ialah dengan menciptakan lembaga perbankan. Fungsi utamanya adalah untuk mengeruk dana masyarakat dengan cepat, sehingga dapat segera mereka manfaatkan untuk menambah modal perusahaannya agar bisa menjadi cepat besar. Ternyata keberadaan lembaga perbankan ini masih dianggap belum cukup, mereka terus mengembangkan

\footnotetext{
${ }^{19}$ Karl Marx, Capital, Penguin, London, 1991 edn, Vol. 3, h.608.

${ }^{20}$ Ibid.
} 
kreatifitasnya. Akhirnya ditemukanlah ide untuk menciptakan sebuah pasar yang unik, yang selanjutnya mereka namakan sebagai pasar saham.

Dengan adanya pasar ini, mereka dapat dengan mudah untuk melempar kertas-kertas sahamnya agar dibeli masyarakat, sehingga mereka segera mendapatkan gelontoran modal yang mampu untuk membuat perusahaan mereka menjadi cepat menggurita. Bagi modal yang secara aktual eksis sama halnya, dan tidak ada perpindahan tangan jika duplikat ini dijual-belikan. Ini menjadi bentuk modal tanpa-bunga karena tidak hanya membuahkan suatu pendapatan tertentu tetapi nilai modal yang diinvestasikan didalamnya dapat dibayar ulang dengan penjualannya. Sejauh akumulasi dari sekuritas ini mencerminkan sebuah ekspansi rel-rel kereta api, pertambangan, kapal uap, dll., ekspansi sebuah proses reproduksi yang aktual...Tetapi sebagai sebuah duplikat yang mana oleh mereka sendiri dapat dipertukarkan selayaknya komoditi, dan , sementara itu sirkulasi sebagai nilai modal, mereka impikan, dan nilai mereka dapat naik dan turun secara cukup independen terhadap gerakan nilai modal aktual terhadap apa yang mereka titelkan..." "Laba dan rugi yang merupakan hasil fluktuasi dalam harga dari kepemilikan titel ini ..adalah alamiah dalam kasus tersebut semakin banyak hasil dari gambling...“. ${ }^{21}$ Begitu bermacamnya gunung-gunung modal ilusi tersebut yang telah terjadi adalah terhalang oleh sebuah grafik. Nilai nasional kontrak masa depan (yakni, perlindungan kontrakan terhadap dan mengantisipasi gerakan masa depan harga-harga komoditi pertanian, indikasi pasar modal, jumlah tingkat bungan dan tingkat pertukaran mata uang) yang diperdagangkan di seluruh perdagangan dunia telah mencapai jumlah US\$14 Triliun setiap tahun. Tentu, spekulator yang sama akan menggunakan dengan baik tingkat yang sama dalam beberapa operasi yang sama suksesnya, sehingga laporan yang aktual mengenai perdangan di masa yang akan datang mungkin seperlima atau sepersepuluh jumlah ini. Tetapi sekalipun itu adalah sebuah grafik yang mengagetkan jika dibandingkan dengan jumlah total modal riil, tidak termasuk real estate, ini secara adalah kepemilikan-pribadi di seluruh dunia yang dihitung oleh Bank Chase Manhattan sebanyak US\$10 Triliun pada tahun $1993 .^{22}$

Pertumbuhan yang mengerikan jumlah uang kertas "mengambang" telah dipicu oleh berbagai macam ekspansi hutang oleh negara, perusahaan dan rumah tangga yang diperoleh

\footnotetext{
${ }^{21}$ Ibid, h. 9

${ }^{22}$ Financial Times, London, 21 Maret 1994.
} 
melalui kredit bank yang terjadi sejak permulaan gelombang depresi panjang pada awal 1970an. Sebab mendasar sistem spekulatif yang membengkak ini adalah berbagai macam ekses kapasitas produktif (yakni, overproduksi aktual dan potensial dari komoditi-komoditi) yang membelenggu sebagian besar industri di seluruh dunia. Modal baru tetap saja terbentuk oleh profit yang dihasilkan setiap tahun yang tidak lama kemudian menemukan kesempatan investasi yang cukup aman setidak-tidaknya pada keuntungan rata-rata, yang mana itu sendiri tetap terdepresi dibandingkan level ia sendiri selama permulaan "gelombang panjang ekspansi" dari akhir 1940an sampai akhir 1960-an. ${ }^{23}$

Fakta bahwa modal ini tidak terinvestasi secara produktif lagi menghasilkan gelombang depresi panjang (khususnya berkurangnya lahan kerja), yang mana berubah menjadi overakumulasi modal, transformasi yang terus tumbuh dari modal ini menjadi kertas tanpa bunga dan, oleh karenanya, spekulasi dalam kertas ini. Aktivitas yang spekulatif tidak hanya dilakukan oleh para "spekulator" profesional. Ia semakin didominasi oleh sebagian besar bank-bank swasta besar dan perusahaan-perusahaan transnasional.Tapi berbagai macam massa kepentingan yang diterima para spekulator adalah dikurangi dari total nilai lebih yang diproduksi waktu itu. Oleh karenanya, fraksi dari nilai lebih tersebut, modal riil, yang disediakan untuk investasi produksi saat itu semakin menurun. Dus, dunia telah dicuci oleh modal illusi karena pemotongan modal riil secara relatif, dan meningkat terus. Sementara begitu besar jumlah uang kertas "mengambang” secara konstan menjelajahi bumi, berpindah dari satu pasar uang ke yang lainnya selama 24 jam penuh, para pemiliknya dimana pasar uang ini berada mempunyai berbagai macam kebijakan.

\section{Eksistensi Sistem Ekonomi Kapitalis Di Indonesia}

Untuk memahami apakah sebuah negara itu bercorak kapitalisme ataukah sebaliknya yaitu sosialisme, maka indikator yang paling mudah untuk digunakan adalah dengan melihat seberapa besar pihak-pihak yang menguasai sektor ekonominya. Jika sektor-sektor ekonomi lebih banyak dikuasai oleh swasta, maka negara tersebut cenderung bercorak kapitalisme dan sebaliknya, jika ekonomi lebih banyak dikendalikan oleh negara, maka lebih bercorak sosialisme. Dengan menggunakan tolok ukur diatas, kita dapat menelusuri sejauh mana cengkeraman kapitalisme telah menjalar ke Indonesia. Sesungguhnya jejak kapitalisme di

${ }^{23}$ Ibid. 
Indonesia dapat ditelusuri ketika Indonesia mulai memasuki era pemerintahan Orde Baru. Pemerintahan Orde Baru dimulai sejak Bulan Maret 1966. Orientasi pemerintahan Orba sangat bertolak belakang dengan era sebelumnya.

Kebijakan Orba lebih berpihak kepada Barat dan menjauhi ideologi sosialis. Dengan membaiknya politik Indonesia dengan negara-negara Barat, maka arus modal asing mulai masuk ke Indonesia, khususnya PMA (Penanaman Modal Asing) dan hutang luar negeri mulai meningkat. Menjelang awal tahun 1970-an atas kerja sama dengan Bank Dunia, Dana Moneter Internasional (IMF), Bank Pembangunan Asia (ADB) dibentuk suatu konsorsium InterGovernment Group on Indonesia (IGGI) yang terdiri atas sejumlah negara industri maju termasuk Jepang untuk membiayai pembangunan di Indonesia. Saat itulah Indonesia dianggap telah menggeser sistem ekonominya dari sosialisme lebih ke arah semikapitalisme (Tambunan, 1998). Memasuki periode akhir 1980-an dan awal 1990-an sistem ekonomi di Indonesia terus mengalami pergeseran. Menilik kebijakan yang banyak ditempuh pemerintah, kita dapat menilai bahwa ada sebuah mainstream sistem ekonomi telah dipilih atau telah 'dipaksakan' kepada negara kita. $^{24}$

Isu-isu ekonomi politik banyak dibawa ke arah libelarisasi ekonomi, baik libelarisasi sektor keuangan, sektor industri maupun sektor perdagangan. Sektor swasta diharapkan berperan lebih besar karena pemerintah dianggap telah gagal dalam mengalokasikan sumberdaya ekonomi untuk menjaga kesinambungan pertumbuhan ekonomi, baik yang berasal dari eksploitasi sumberdaya alam maupun hutang luar negeri. Pakto '88 dapat dianggap sebagai titik tonggak kebijakan libelarisasi ekonomi di Indonesia. Menjamurnya industri perbankan di Indonesia, yang selanjutnya diikuti dengan terjadinya transaksi hutang luar negeri perusahaan-perusahaan swasta yang sangat pesat, mewarnai percaturan ekonomi Indonesia saat itu. ${ }^{25}$ Masa pembangunan ekonomi Orde Baru-pun akhirnya berakhir. Puncak dari kegagalan dari pembangunan ekonomi Orba ditandai dengan meledaknya krisis moneter, yang diikuti dengan ambruknya seluruh sendisendi perekonomian Indonesia.

Pasca krisis moneter, memasuki era reformasi, ternyata kebijakan perekonomian Indonesia tidak bergeser sedikitpun dari pola sebelumnya. Bahkan semakin liberal. Dengan

\footnotetext{
${ }^{24}$ Ibid

${ }^{25}$ Rachbini, Ekonomi Politik Uang (Jakarta: Rajawali Press, 2001), h.15.
} 
mengikuti garis-garis yang telah ditentukan oleh IMF, Indonesia benar-benar telah menuju libelarisasi ekonomi.

\section{Kesimpulan}

Dari hasil uraian tersebut diatas dapat disimpulkan bahwa penerapan sistem ekonomi kapitalis di Indonesia masih berlangsung sampai saat ini, karena ada beberapa faktor yang tetap dilaksanakan oleh pemerintah, adalah sebagai berikut:

1. Dihapuskannya berbagai subsidi dari pemerintah secara bertahap. Berarti, harga dari barangbarang strategis yang selama ini penentuannya ditetapkan oleh pemerintah, selanjutnya secara berangsur diserahkan sepenuhnya pada mekanisme pasar.

2. Nilai kurs rupiah diambangkan secara bebas (floating rate). Sesuai dengan kesepakatan dalam LoI dengan pihak IMF, penentuan nilai kurs rupiah tidak boleh dipatok dengan kurs tetap (fix rate). Dengan kata lain, besarnya nilai kurs rupiah harus dikembalikan pada mekanisme pasar.

3. Privatisasi BUMN. Salah satu ciri ekonomi yang liberal adalah semakin kecilnya peran pemerintah dalam bidang ekonomi, termasuk didalamnya adalah kepemilikan asset-asset produksi. Dengan dijualnya BUMN kepada pihak swasta, baik swasta nasional maupun asing, berarti perekonomian Indonesia semakin liberal.

4. Peran serta pemerintah Indonesia dalam kancah WTO dan perjanjian GATT. Dengan masuknya Indonesia dalam tata perdagangan dunia tersebut, semakin memperjelas komitmen Indonesia untuk masuk kubangan libelarisasi ekonomi dunia atau kapitalisme global. 


\section{DAFTAR PUSTAKA}

Becker, Shak dan Hakim, Globalisasi, Kapitalim Global dan Media, Media Global, 1999.

Financial Times, London, 21 Maret 1994

George Ritzer, Modem Sosialical Theory, university of Chicago press, 1996

Hoogvelt, Globalization and The Post Colonial World, Johns Hapkins University press, 1997

Jameson, The Cultural Logic of late Capitalism, University Pres, 1991

Karl Marx, Capital : A Critique of Political Economic, 1909.

McChesney, Wood \& Foster, Capitalism and The Information Age : the Political Economy Of The Global Comunication Revolution, university of Chicago press, 1998

Mubyarto, Reformasi Sistem Ekonomi: Dari Kapitalisme menuju Kerakyatan, Aditya Media, Jakarta. 1999.

Nicolas Garnham, Capitalism and Communication Global Culture and The Economics Of Information, Yale UnivesityPress, New Haven, C,T, 1999

Rachbini, Ekonomi Politik Uang, Rajawali Press, Jakarta, 2001

Samuelson dan Nordhaus, Economics, Live Journal, hc, 1999

Thomas L. Mcphail , Global Communication : Theories Stakeholders and Trends, 2002.

V.I. Lenin, The highest Strage Of Capitalism, University Press, 1916. 